\title{
Alteration of dry matter accumulation under soil moisture fluctuation stress in rice (Oryza sativa L.)
}

\author{
${ }^{*}$ Cut Nur Ichsan ${ }^{1,2}$, Bakhtiar Basyah ${ }^{1,3}$, Sabaruddin Zakariaa ${ }^{1,4}$, Efendi Efendi ${ }^{1,4}$ \\ ${ }^{1}$ Graduate School (Agricultural Sciences) Universitas Syiah Kuala, Banda Aceh 23111, Indonesia \\ ${ }^{2}$ Laboratory of Experimental Farm and Green House Department of Agrotechnology, Faculty of Agriculture, \\ Universitas Syiah Kuala, Banda Aceh 23111, Indonesia \\ ${ }^{3}$ Laboratory of plants breeding Department of Agrotechnology, Faculty of Agriculture, Universitas Syiah Kuala, \\ Banda Aceh 23111, Indonesia \\ ${ }^{4}$ Laboratory of seed technology Department of Agrotechnology, Faculty of Agriculture, Universitas Syiah Kuala, \\ Banda Aceh 23111, Indonesia
}

\section{*Corresponding author: cnichsan64@gmail.com}

\begin{abstract}
Drought-flood abrupt alterations (DFAA) is a condition in drought season when sudden rain inundate rice plants. These events are due to the high frequency of extreme climate events that might pose a threat to rice productivity. DFAA causes cumulative stress on rice which affects crop growth and alters dry matter accumulation. This study aims to understand the effect of DFAA to dry matter accumulation by assessing six rice varieties under DFAA. Three treatments were provided such as continuously irrigated as non-water stress (NS) as a control; drought to water stress -35 kPa (DFAA1) followed by sudden flood; drought to severe water stress $-70 \mathrm{kPa}$ (DFAA2) followed by abrupt floods; repeated until harvest. The study found that the alteration of dry matter accumulation was determined by root length, root weight, shoot length and shoot weight. Only varieties that are able to increase root depth under water stress fluctuation will be able to maintain the yield. The results of study showed that root depth was positively correlated with shoot length $(r=0.68)$, shoot weight $(r=0.62)$, root weight $(r=0.57)$, percentage of filled grain $(r=0.55)$ and number of filled grain per hill $(r=0.49)$. Shoot length was positively correlated with shoot weight $(r=$ $0.83)$, root weight $(r=0.75)$ and the number of filled grain $(r=0.62)$, while shoot weight was only positively correlated with root weight $(r=0.88)$. This means that only root depth and shoot length can increase the seed setting rate and the number of filled grains per hill. Furthermore, at DFAA2, the percentage of filled grain was highest in Sipulo followed by Bo Santeut, Sanbei, Towuti and Situ Patenggang, which mean that varieties with deeper and heavier root dry weight can maintain higher yields than shallow and low root dry weight. The result of the study may allow to select rice varieties that are resistant to multilevel waterstress and able to maintain the potential yield, by looking at root depth, root dry weight, and through their grain yield in general. These traits could become key indicators for resistance to DFAA stress in rice. It is also necessary to pay attention to the fluctuation of soil water content in critical phases, especially in the reproductive phase and grain filling.
\end{abstract}

Keywords: abrupt; climate change; drought; flooded; soil water potential; yield.

Abbreviations: DAP_days after planting; DFAA_drought-flood abrupt alternation; NS_non-stress

\section{Introduction}

Rice is a plant that is strongly influenced by environmental factors (Upadhayaya and Panda, 2019). These factors are exacerbated by climate change that causes frequent extreme climate events (IPPC, 2014), namely drought-flood abrupt alteration (DFAA) in which drought and floods often occur simultaneously, causing plants to experience accumulated stress (Gao et al., 2019; Xiong et al., 2020; Zhu et al., 2020). The DFAA causes photosynthetic inhibition after soil moisture fluctuation stress. This DFAA stress at the heading causes differences in air pressure on leaves which causes differences in water use of leaves, which affect rice modelling and production. This accumulative stress causes change in the photosynthetic properties of plants, especially rice (Zhu et al., 2019). These extreme climate events often destroy planted areas (Zhang et al., 2015) and threaten agricultural production (Dong et al., 2011). Drought, especially followed by inundations, reduces dry matter production, even in drought resistant varieties (Suralta et al., 2010).

A change in rainfall patterns is another type of environmental stress (Khalil et al., 2020), in which 
causes a negative effect on crop production (Bano et al., 2020; Gautam et al., 2020). The physiology of rice leaves can be affected by rewatering after drought stress (Xiong et al., 2018). Drought followed by flood can increase the number of panicles and decrease the level of seed setting rates in rice (Xiong et al., 2020). Furthermore, it also causes rooting activity to increase and mitigate the effects of inundation (Xiong et al., 2018). Rice is a semi-aquatic plant that requires sufficient water (Upadhayaya and Panda, 2019; IPPC, 2014) where a lack of water affects rice production (Kumar et al., 2020).

Furthermore, drought condition causes physiological, morphological and biochemical changes in rice (Pandey and Shukla, 2015) that potentially threatens world rice production (Wassman et al., 2009). Extreme climate change is a threat to food security, and the effects of climate change on rice production must be reduced (Mukamuhirwa et al., 2019). Drought has a negative effect on growth and development of rice because. It decreases photosynthetic rate (Oh-e et al., 2007) and the quality of rice (Mukamuhirwa et al., 2019). Overall, rice production is significantly influenced by climate change (Korres et al., 2016).

Simultaneously, drought affects grain quality (Chen et al., 2020) and has a negative effect on rice growth and development (Huang et al., 2018). In dry conditions, drought affects starch accumulation in grains (Prathap et al., 2019), even the yields of super rice become 2.0 to $2.9 \mathrm{t} \mathrm{ha}^{-1}$ (Marcaida et al., 2014). Meanwhile, sensitive drought varieties such as IR 64 have a significant change in starch accumulation in the grain under water-stress conditions (Prathap et al., 2019). Water stress causes changes in dry matter accumulation (Gao et al., 2018) and the partition of starch grains (Duan et al., 2020). Meanwhile, soil moisture fluctuation stress changes the photosynthetic properties of rice (Zhu et al., 2020).

Indeed, the resistance of rice to water stress depends on the accumulation of dry matter and starch partitions in the grains (Kumar et al., 2006). Furthermore, drought induces increased antioxidant capacity (Nahar et al., 2018). However, under stress conditions, grains have a higher nutritional value (Mukamuhirwa et al., 2019). Several studies have shown that sudden flooding after a drought causes lower growth and yield (Gao et al., 2019; Shao et al., 2015) and affects the rate of photosynthesis (Lu et al., 2016; 2017; Zhu et al., 2019).

The purpose of this study is to determine the effect of soil moisture fluctuation stress on six rice varieties that experience multi-stages soil moisture fluctuation stress and to determine the accumulation of dry matter based on root, shoot length, shoot, root weight, root to shoot ratio, number of filled grains per panicle, seed setting rate, number of filled grains per hill and the harvest index.

\section{Results and discussion}

The interaction effect of soil moisture fluctuation stress and variety on root length, shoot length, shoot weight, root weight, root to shoot ratio, the number of filled grains per panicle, seed setting rate, the number of filled grains per hill and the harvest index can be seen in Table 1.

There was a decrease in root depth with different levels of reduction in each variety when compared to non-stress condition, when the drought-flood abrupt alteration (DFAA) repeatedly occurred until harvest, both in DFAA1 (drought up to $-35 \mathrm{Kpa}$ and then abrupt inundation) and DFAA2 treatments. Furthermore, when drought stress induced by the dropping soil water potential to $-70 \mathrm{kPa}$ followed by abrupt inundation (in DFAA2), root length and shoot length were highest in Sipulo, followed by Bo Santeut and Sanbei (test varieties), which were longer than Situ Patenggang and Towuti (positive control of waterstress-tolerant varieties). This is in line with the research results of Kumar et al. (2020) and Wang et al. (2010). The weight differences in shoot and root in the six studied varieties was at various levels of soil moisture fluctuation stress. In DFAA2, the highest shoot weight was found in the Sipulo variety, followed by Bo Santeut and Sanbei which were higher than Towuti, Situ Patenggang; and IR 64 (the negative control of sensitive water-stress variety) (Prathap et al., 2019; Swapna et al., 2017; Kumar et al., 2020; Nahar et al., 2018).

Likewise, the highest root weight was found in Sipulo, followed by Bo Santeut and Sanbei compared to IR 64, Towuti and Situ Patenggang. These higher root and shoot weights indicated that the amount of partition of dry matter in those three local varieties was greater compared to the check varieties. Furthermore, the highest root to shoot ratio was found in Bo Santeut, followed by Situ Patenggang, IR 64, Sipulo, Sanbei and Towuti. This shows that the distribution of carbon in the roots and shoots is varied between varieties. This is in line with the research results of Korres et al. (2017). Furthermore, under water-stress conditions, plant genotypes have varied growth rates between varieties. This was also in line with the research results of Chutipaijit et al. (2016). Moreover, response of plant morphology to drought was seen in growth. Growth can be in the form of dry matter accumulation in the roots and canopy. Meanwhile, for yields, there was a decrease in the yield component under different soil moisture fluctuation stress. The number of filled grains of rice decreased in all varieties, except in Situ Patenggang and Sipulo which showed an increase under DFAA2. This is due to the ability of Situ Patenggang variety (the positive control of waterstress-tolerant variety) to accumulate starch in grains under water-stress conditions, which is the characteristic of drought-tolerant varieties (Kumar et al., 2020). Meanwhile, under DFAA2 conditions, the lowest number of filled grains per hill was in the Sanbei variety. Furthermore, the seed setting rate was decreased in all varieties as water stress increased. However, under DFAA2 condition, the highest seed setting rate was observed in Sipulo, followed by Bo Santeut and Sanbei, which were higher than Towuti and Situ Patenggang as the positive control of waterstress-tolerant varieties.

The ability of local varieties - Sipulo, Bo Santeut and Sanbei - to accumulate starch under conditions of 
severe water stress is in line with the research results of Kamarudin et al. (2018). There was an increase in the harvest index for tolerant local varieties and a decrease in the harvest index for sensitive genotypes such as IR 64 under water-stress conditions. However, the number of filled grains of rice decreased in all varieties at various levels of water stress. In DFAA1, the lowest decrease of number of filled grains was in Sipulo, followed by Towuti, Sanbei, Situ Patenggang and Bo Santeut. The largest decrease in the number of filled grains of rice was found in IR 64 which is a waterstress-sensitive variety (Kamarudin et al., 2018; Nahar et al., 2018; Liu et al., 2011). Meanwhile, in DFAA2, the highest number of filled grains of rice were in Situ Patenggang, followed by Sipulo, Bo Santeut and Sanbei.

The harvest index was decreased with increased soil moisture fluctuation stress. In DFAA1, the highest reduction rate was in IR 64, followed by Bo Santeut. Meanwhile, in the same situation, for Situ Patenggang, Sanbei, Sipulo and Towuti there was an increase in the harvest index. This was because in DFAA1 conditions, the average content of starch was increased due to water-stress conditions. There was an increase in the accumulation of starch to grain, but the accumulation of dry matter to the shoot in the form of leaves in the vegetative and reproductive phases decreased in water-stress conditions. This is in line with the research results of Zhang et al. (2009). Drought can increase the weight of filled grains due to higher starch accumulation. However, there were also studies that reported a decrease in starch in drought conditions (Zhu et al., 2017). Meanwhile, in DFAA2, the harvest index was decreased in Towuti, Situ Patenggang, IR 64, Sanbei and Bo Santeut.

However, in DFAA2, for Sipulo, the number of filled grains and seed setting rate was higher when compared to other varieties. This shows that Sipulo as a local variety has a better mechanism for the accumulation of dry matter to grains so that the harvest index was higher under DFAA2. This higher harvest index was due to the ability to produce antioxidants so that it can protect cells from damage and maintain starch production in chloroplast. So, the weight of grains per hill remains high and the harvest index increases. This is in line with the findings of Skirycz et al. (2010) and Wang et al. (2013).

The ability of different varieties in accumulating dry matter can be seen in the root and canopy growth in the vegetative phase of the six varieties. Fig. 1. shows that Sipulo, Sanbei and Bo Santeut have root and shoot morphologies that are more developed under soil moisture fluctuation stress than other varieties.

There were significant differences in root and shoot growth among varieties under different soil moisture fluctuation stress. In DFAA1, the photosynthetic partition to the roots of the Sipulo, Sanbei and Bo Santeut (test variety) at the age of one month after planting was greater than those in Situ Patenggang (the water-stress variety for upland and lowland), Towuti (the water-stress variety for lowland) and IR 64 (the susceptible water-stress variety). In DFAA2, it was seen that the Sipulo variety had larger solid roots represented by photosynthetic partitions to the roots than the other varieties.

The matrix correlation of parameters under different soil moisture fluctuation stress and variety is shown in Table 2. There was a positive correlation between root depth and shoot length $(r=0.68)$, shoot weight $(0.62)$, root weight $(0.57)$, seed setting rate $(0.58)$ and the number of filled grains per hill (0.49). Also shoot length was positively correlated with shoot weight (0.83), root weight (0.75) and the number of filled grains per hill (0.62). Furthermore, shoot weight was closely related to root weight.

This shows that the accumulation of dry matter in the shoot is highly dependent on the depth of the roots. The deeper the roots, the more water and nutrients can be taken in for shoot formation. Root depth also affects root weight because the deeper the roots are, the more of dry matter is allocated to the roots, which increases the root weight. Root depth is also correlated with the seed setting rate because the deeper the roots, the more water can be taken in, so the formation of starch to be translocated into the grains is higher.

Cell activity can continue under water-stress conditions so that more photosynthate partitions are allocated to the filled grain, causing an increase in the percentage of filled grains. The amount of filled grain was also positively correlated with root depth due to the photosynthetic component consisting of water and $\mathrm{CO} 2$ from the air, while water from the soil was uptake by the plant roots. So that more uptake water leads to a greater amount of photosynthate that produced and allocated to the grain to increase the amount of filled grain. Shoot length was also closely related with shoot weight, root weight and the number of grains per hill. The longer shoots were heavier creating plants with deeper roots. Because there were more leaves, photosynthate was produced to be allocated to the roots to increase the ability of the roots to take water. The root weight was increased in plants with long shoots. Shoot lengths were also closely related with the number of filled grains per hill. The longer the shoot, the more leaves and photosynthate were produced to be transferred into grains.

Shoot weight was also positively correlated with root weight. The heavier shoot produced more photosynthate that could be translocated to the roots. Likewise, the heavier the roots, the longer the distribution and the deeper the roots. Therefore, more water and nutrients were taken for various metabolic processes to produce dry matter. Thus, more dry matter accumulation was produced for the formation of shoots and roots.

\section{Materials and methods}

\section{Materials and growth condition}

This study was conducted on six rice varieties consisting of Situ Patenggang, Towuti, IR 64, and three local varieties namely Sipulo, Sanbei and Bo Santeut. In this sense, Towuti is the positive control of tolerant variety for lowland and Situ Patenggang is the positive control 
Table 1. Interaction effect between soil moisture fluctuation stress and variety on root depth, shoot length, shoot weight, root weight, root to shoot ratio, number of filled grains per panicle, seed setting rate, number of filled grains per hill and harvest index.

\begin{tabular}{|c|c|c|c|c|c|c|c|c|}
\hline Parameters & & $\begin{array}{c}\text { Situ } \\
\text { Patenggang }\end{array}$ & Towuti & IR 64 & Sipulo & Sanbei & Bo Santeut & HSD 0.05 \\
\hline \multirow[t]{3}{*}{ Root depth (cm) } & NS & $36.00 c$ & $20.67 a$ & $37.33 c$ & $45.33 d$ & $39.67 d$ & $41.67 d$ & \multirow[t]{3}{*}{6.00} \\
\hline & DFAA1 & $29.33 b c$ & $23.67 a$ & $20.67 a$ & $32.67 \mathrm{c}$ & $41.33 d$ & $30.00 \mathrm{~b}$ & \\
\hline & DFAA2 & $25.33 b c$ & $19.33 a$ & $18.67 a$ & $30.67 \mathrm{~b}$ & $25.00 \mathrm{~b}$ & $26.67 b$ & \\
\hline \multirow[t]{3}{*}{ Shoot length $(\mathrm{cm})$} & NS & $108.00 \mathrm{e}$ & $105.50 \mathrm{e}$ & $98.67 d$ & $147.50 \mathrm{~h}$ & $118.67 \mathrm{f}$ & $115.50 f$ & \multirow[t]{3}{*}{4.68} \\
\hline & DFAA1 & $106.83 \mathrm{e}$ & $104.83 \mathrm{e}$ & $97.83 c$ & $127.67 \mathrm{~g}$ & $104.37 \mathrm{e}$ & $106.83 e$ & \\
\hline & DFAA2 & 104.00de & $81.00 a$ & $94.50 c$ & $118.33 f$ & $85.33 b$ & $97.67 \mathrm{c}$ & \\
\hline \multirow[t]{3}{*}{ Shoot weight (g) } & NS & $26.49 a$ & $46.85 c$ & $36.09 \mathrm{~b}$ & $165.64 i$ & $56.51 d$ & $93.21 \mathrm{~h}$ & \multirow[t]{3}{*}{3.11} \\
\hline & DFAA1 & $25.85 a$ & $35.86 \mathrm{~b}$ & $33.76 \mathrm{~b}$ & $77.62 \mathrm{~g}$ & $44.85 c$ & $58.59 e$ & \\
\hline & DFAA2 & $25.25 a$ & $27.52 a$ & $27.56 a$ & $73.56 f$ & $35.18 b$ & $53.08 d$ & \\
\hline \multirow[t]{3}{*}{ Root weight (g) } & NS & $7.61 \mathrm{a}$ & $25.80 \mathrm{e}$ & $23.40 \mathrm{e}$ & $42.85 \mathrm{~g}$ & $17.44 d$ & $26.39 \mathrm{e}$ & \multirow[t]{3}{*}{2.09} \\
\hline & DFAA1 & 7.31a & $11.38 \mathrm{~b}$ & $13.50 c$ & $27.34 f$ & $16.84 d$ & $25.60 \mathrm{e}$ & \\
\hline & DFAA2 & 7.09a & $7.31 \mathrm{a}$ & $8.23 a$ & $23.43 e$ & $11.56 \mathrm{~b}$ & $14.45 c$ & \\
\hline \multirow[t]{3}{*}{ Root to shoot ratio } & NS & $0.10 a$ & $0.02 a$ & $0.09 a$ & $0.18 \mathrm{~b}$ & $0.09 a$ & $0.09 a$ & \multirow[t]{3}{*}{0.13} \\
\hline & DFAA1 & $0.08 a$ & $0.08 a$ & $0.05 a$ & $0.26 c$ & $0.14 a$ & $0.10 a$ & \\
\hline & DFAA2 & $0.34 d$ & $0.11 a$ & $0.29 c$ & $0.25 c$ & $0.12 a$ & $0.56 \mathrm{e}$ & \\
\hline \multirow{3}{*}{$\begin{array}{l}\text { Number of filled grains per } \\
\text { panicle (grain) }\end{array}$} & NS & 203.77e & $127.27 \mathrm{c}$ & $116.53 b$ & $121.93 b$ & $211.20 \mathrm{e}$ & $125.04 \mathrm{~b}$ & \multirow[t]{3}{*}{11.19} \\
\hline & DFAA1 & $153.73 c$ & $130.00 c$ & $116.47 \mathrm{~b}$ & $114.31 b$ & $130.07 c$ & $122.27 \mathrm{~b}$ & \\
\hline & DFAA2 & $190.40 d$ & $116.86 b$ & $115.81 b$ & $130.00 c$ & $100.05 a$ & $119.60 \mathrm{~b}$ & \\
\hline \multirow[t]{3}{*}{ Seed setting rate (\%) } & NS & $67.91 \mathrm{~g}$ & $60.51 f$ & $55.77 \mathrm{e}$ & 85.29 & $64.66 \mathrm{~g}$ & $68.82 \mathrm{~h}$ & \multirow[t]{3}{*}{3.51} \\
\hline & DFAA1 & $48.45 d$ & $53.42 \mathrm{e}$ & $37.67 \mathrm{~b}$ & $60.60 f$ & $54.12 \mathrm{e}$ & $55.84 \mathrm{e}$ & \\
\hline & DFAA2 & $32.86 a$ & $40.13 b$ & $34.41 a$ & $49.85 d$ & $45.53 c$ & $49.08 d$ & \\
\hline \multirow{3}{*}{$\begin{array}{l}\text { Number of filled grains per } \\
\text { hill (grain) }\end{array}$} & NS & $921.25 d$ & $961.08 \mathrm{~d}$ & $444.08 \mathrm{~b}$ & $900.93 d$ & $875.34 d$ & $606.77 \mathrm{~b}$ & \multirow[t]{3}{*}{173.4} \\
\hline & DFAA1 & $669.09 c$ & $933.28 d$ & $269.77 a$ & $900.17 d$ & $827.17 d$ & $564.75 b$ & \\
\hline & DFAA2 & $638.95 c$ & $283.39 a$ & $215.74 a$ & $446.16 b$ & $382.55 a$ & $413.09 \mathrm{~b}$ & \\
\hline \multirow[t]{3}{*}{ Harvest index } & NS & $0.59 f$ & $0.49 \mathrm{e}$ & $0.51 \mathrm{e}$ & $0.22 a$ & $0.39 c$ & $0.30 \mathrm{~b}$ & \multirow[t]{3}{*}{0.056} \\
\hline & DFAA1 & $0.74 \mathrm{~g}$ & $0.40 \mathrm{~d}$ & $0.33 c$ & $0.35 c$ & $0.50 \mathrm{e}$ & $0.24 a$ & \\
\hline & DFAA2 & $0.40 \mathrm{~d}$ & $0.35 c$ & $0.26 \mathrm{~b}$ & $0.34 c$ & $0.24 a$ & $0.20 a$ & \\
\hline
\end{tabular}

Data followed by the same letter within the same column for each parameter indicate no significant difference at $\mathrm{P}<0.05$ level (HSD test) coefficient of variation (CV).

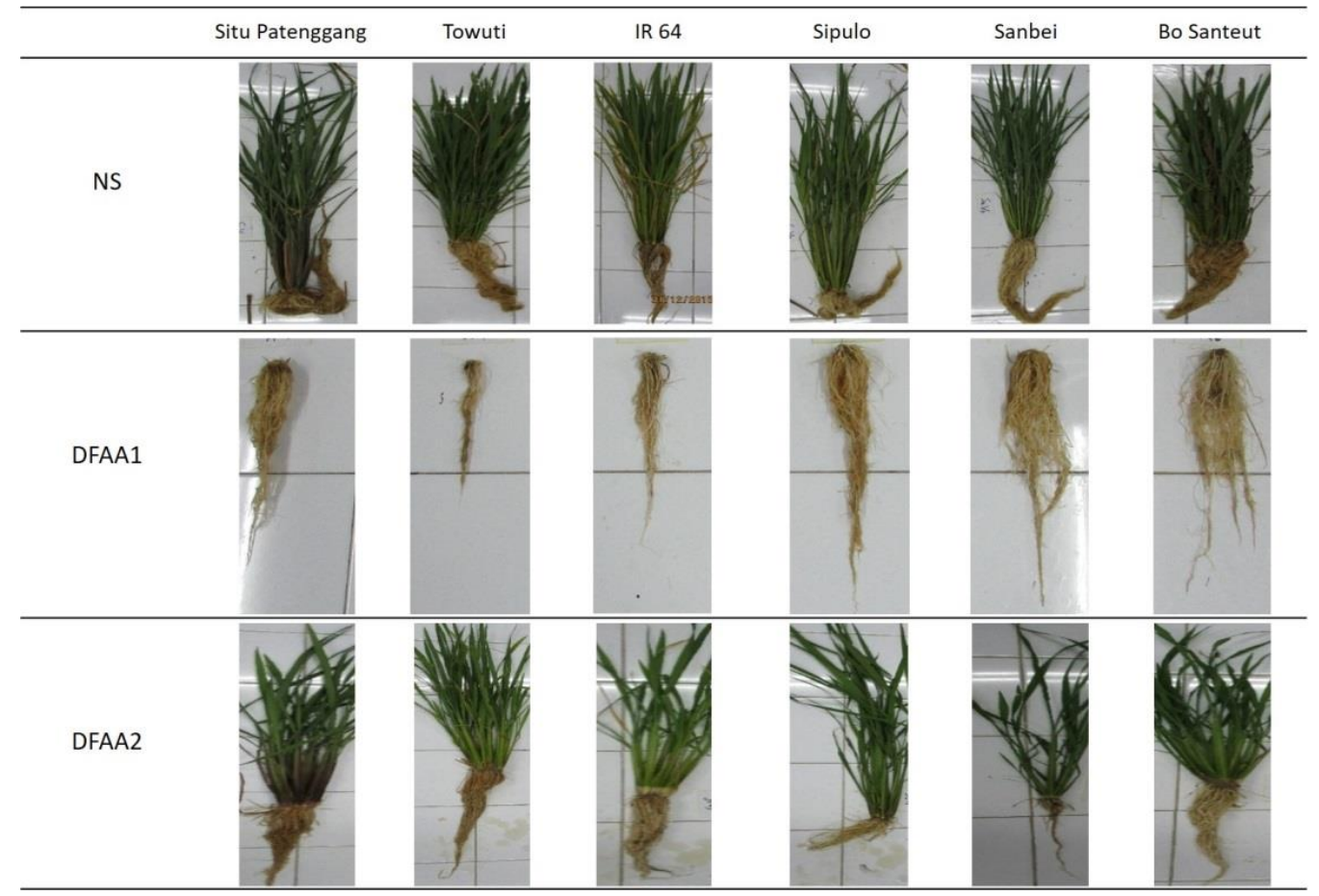

Fig 1. Differences of photosynthate partition in roots and shoots in six varieties under non-stress and water stress conditions. Overall, there were changes in the roots in DFAA1, when compared to NS condition, but not as much as in DFAA2. Regarding shoots, for water stress tolerant varieties, changes of shoots were not as large as in water stresssensitive varieties. NS (non-stress water condition); DFAA1 (dry-flood abrupt alteration at water stress condition -35 Kpa); DFAA2 (dry-flood abrupt alteration at sever water stress level -70 Kpa). 
Table 2. Correlation matrix between parameters under different soil moisture fluctuation stress and varieties.

\begin{tabular}{|c|c|c|c|c|c|c|c|c|c|}
\hline & $\mathrm{X} 1$ & $\mathrm{x} 2$ & $\mathrm{x} 3$ & $\mathrm{X} 4$ & $\mathrm{x} 5$ & $\mathrm{x} 6$ & $\mathrm{X} 7$ & $\mathrm{x} 8$ & X9 \\
\hline Root depth $(\mathrm{cm})$ & 1 & $0.685^{* *}$ & $0.623^{* *}$ & $0.577^{*}$ & -0.105 & 0.264 & $0.551^{*}$ & $0.490^{*}$ & 0.105 \\
\hline Shoot length $(\mathrm{cm})$ & & 1 & $0.836^{* *}$ & $0.758^{* *}$ & 0.022 & 0.198 & 0.336 & $.628^{* *}$ & -0.059 \\
\hline Shoot weight (g) & & & 1 & $0.888^{* *}$ & 0.082 & -0.197 & 0.443 & 0.322 & -0.437 \\
\hline Root weight (g) & & & & 1 & -0.085 & -0.309 & 0.388 & 0.348 & -0.336 \\
\hline Root to shoot ratio & & & & & 1 & -0.052 & -0.336 & -0.257 & -0.432 \\
\hline $\begin{array}{l}\text { Number of filled grains per panicle } \\
\text { (grain) }\end{array}$ & & & & & & 1 & 0.232 & 0.451 & 0.462 \\
\hline Seed setting rate (\%) & & & & & & & 1 & 0.335 & 0.058 \\
\hline Number of filled grains per hill (grain) & & & & & & & & 1 & 0.383 \\
\hline Harvest index & & & & & & & & & 1 \\
\hline
\end{tabular}

Table 3. Minimum and maximum temperature, relative humidity and photoperiod.

\begin{tabular}{|lcccc|}
\hline Month & \multicolumn{3}{c}{ Average } & Relative humidity \\
$(\%)$ & Average photoperiodicity $(\mathrm{h})$ \\
\hline November & 23.0 & 32.6 & $80-90$ & 12 \\
\hline December & 21.0 & 33.4 & $77-89$ & 12 \\
\hline January & 22.0 & 33.8 & $78-91$ & 12 \\
\hline February & 22.0 & 34.6 & $78-91$ & 12 \\
\hline March & 16.0 & 34.8 & $77-88$ & 12 \\
\hline
\end{tabular}

of tolerant variety for both upland and lowland and (Sujinah and Jamil, 2016; Yugi et al., 2011).

IR 64 is a negative control of water-stress-sensitive variety (Nahar et al., 2018; Kumar et al., 2020). The study was conducted in a plastic house at the experimental farm and greenhouse laboratory of the Faculty of Agriculture, Syiah Kuala University, Band Aceh, Aceh, Indonesia $\left(95^{\circ} 22^{\prime} 34,49^{\circ} \mathrm{T}\right.$ longitude, $5^{\circ}$ $34^{\prime} 3.44^{\circ} \mathrm{U}$ latitude). The altitude was $3 \mathrm{~m}$ above sea level and the annual rainfall was $1383.6 \mathrm{~mm}$ with a maximum temperature of $33.25^{\circ} \mathrm{C}$ and a minimum temperature of $23.75^{\circ} \mathrm{C}$. The study was conducted from November 2015 to March 2016.

The study was carried out in pot experiment, using a 19liter volume pot filled with $10 \mathrm{~kg}$ of podsolid soil. The soil was soaked and stirred to form a mud texture and then soaked for two weeks. A factorial randomised block split plot design was used with three levels of soil water potential with the six rice varieties (Situ Patenggang, Towuti, IR 64, Sipulo, Sanbei, Bo Santeut). Split plot with three replications was used with a total 162 pots for 3 blocks. The soil water stress treatments became the main plots, while the varieties became subplots. The main plots consisted of non-stress (NS) treatment; drought-flood abrupt alteration 1 and 2 (DFAA1 and DFAA2) treatments. The control (NS) were irrigated continuously for up to $2 \mathrm{~cm}$ above the soil surface from the age of 15 days after planting (DAP) until harvest. While DFAA1 and DFAA2 were inundated for $2 \mathrm{~cm}$ as well, then allowed to dry naturally until the soil water potential drops to $-0.35 \mathrm{kPa}$ (DFAA1) and $-0.70 \mathrm{kPa}$ (DFAA2) then immediately watered up to $2 \mathrm{~cm}$ above the soil surface, repeated until harvest.

Plants were given soil water fluctuation stress repeatedly in the growing phase to see the plant resistances to soil water fluctuation stress at various growing stages. Soil water fluctuation stress control was done by installing a tensiometer Jet Fill Model 2725 (Soil moisture Equipment Corp., Santa Barbara, California, USA) and Global Water Logger II Version 2.10 (produced by Global Water, 11390 Amalgam Way, Gold River, California, 95670, USA, www.globalw.com) to ensure the same level of soil water stress in the pots in DFAA1 and DFAA2 (soil water potential decreased to -35 and -70 $\mathrm{KPa}$ ) before rewatering until flooded $2 \mathrm{~cm}$ above the soil surface. Soil water potential observations were conducted at $7 \mathrm{am}, 1 \mathrm{pm}$ and $6 \mathrm{pm}$ every day.

Fertilisation was carried out by giving $0.5 \mathrm{~g}$ of urea at planting, aged 30 and 60 days after planting (DAP). $\mathrm{KCl}$ and Sp36 were given $0.5 \mathrm{~g}$ at planting time. N-P-K (15\%$15 \%-15 \%)$ was given $2.25 \mathrm{~g}$ at planting time and at an age of 30 DAP. Rice seedlings were planted 12 days after sowing. Each seedling was planted in each pot on 15 November 2015 and harvested on 19 March 2016. The daily weather conditions during the study can be seen in Table 3.

\section{Sampling and measurement}

Dry matter accumulation measurements based on the morphology of root depth, shoot length, shoot weight, root weight, the number of filled grains, seed setting rate, filled grains per hill and the harvest index were carried out after the harvest. After the harvest, the biomass was measured including the length and depth of the roots. They were dried at $60^{\circ} \mathrm{C}$ for $3 \times 24$ hours until they reached a constant weight. Measurements were based on IRRI (2012). 


\section{Statistical analysis}

Data were analysed by analysis of variants (ANOVA) to determine the effect of soil moisture fluctuation stress and variety on the parameters studied (Gomes and Gomes, 1984). Microsoft Excel version 2013 was used. Meanwhile, to see the significant difference between the levels of treatment, the honesty significant difference test (HSD) $p<0.05$ was used. A correlation test between parameters using Pearson correlation was performed using SPSS statistical analysis package version 26.0 (IBM, Chicago, USA).

\section{Conclusion}

There were varied accumulation of dry matter for each variety at different levels of soil moisture fluctuation stress. The drought-tolerant varieties can increase the accumulation of dry matter in the grain and increase the harvest index. Particularly, the accumulation of dry matter in the roots was closely related to the accumulation of dry matter in the shoot and grain. Local varieties of Sipulo, Sanbei and Bo Santeut have a greater accumulation of dry matter in the roots so that the depth and dry weight of the roots were higher than the positive control of water-stress-tolerant varieties, Situ Patenggang and Towuti. Likewise, the accumulation of dry matter in filled grains under DFAA2 in Situ Patenggang, Sipulo and Bo Santeut was higher than in the Towuti, Sanbei and IR 64 varieties. The accumulation of dry matter in roots and the grains could be key indicators of rice tolerance to soil moisture fluctuation stress. Local varieties of Sipulo and Bo Santeut can be improved to become water-stress-tolerant varieties. Various agronomic techniques are needed to cope with soil moisture fluctuation stress under climate change conditions.

\section{Acknowledgements}

This study received no specific grant from any funding agency in the public, commercial or non-profit sectors. The authors would like to thank the chief experimental farm and greenhouse laboratory of the Agrotechnology department in the Faculty of Agriculture at Syiah Kuala University, Banda Aceh, Aceh, Indonesia for supporting and facilitating this study.

\section{References}

Bano C, Amist N, Singh NB (2020) Role of polyamines in plants abiotic stress tolerance: Advances and future prospects. In: Durgesh Tripathi, Vijay Singh, Devendra Chauhan, Shivesh Sharma, Sheo Prasad, Nawal Kishore Dubey, Naleeni Ramawat (ed) Plant life under changing environment, 18th edn. Academic Press, Cambridge, Massachusetts. 481492.

Chen Z, Chen H, Jiang Y, Jinping W, Khan A, Li P, Cougui CC (2020) Metabolomic analysis reveals metabolites and pathways involved in grain quality traits of highquality rice cultivars under a dry cultivation system. Food Chemistry. Food Chem. 326: 126-845.
Chutipaijit S (2016) Changes in physiological and antioxidant activity of indica rice seedlings in response to mannitol-induced osmotic stress. Cultural Research 76 (1) January Chilean Journal of Agricultural Research. 76: 455-462.

Dong QT, Li MS, Liu J, Wang CY (2011) Spatio-temporal evolution characteristics of drought of spring maize in northeast China in recent 50 years. Journal of Natural Disasters. 20: 52-59.

Duan H, Tong, H, Zhu A, Zhang H, Liu L (2020) Effects of heat, drought and their combined effects on morphological structure and physicochemical properties of rice (Oryza sativa L.) starch. J Cereal Sci. 95: 103059.

Gao Q, Sun J, Tong H, Wang W, Zhang Y, Zhang G, Ma $D$, Chen W (2018) Evaluation of rice drought stress response using carbon isotope discrimination. J Plant Physiol. 132: 80-88.

Gao, Y., Hu, T., Wang Q, Yuan H, Yang J (2019) Effect of drought-flood abrupt alternation on rice yield and yield components. Crop Science. 59: 280-292.

Gautam A, Pandey P, Pandey AK (2020) Proteomics in relation to abiotic stress tolerance in plants. In: Durgesh Tripathi, Vijay Singh, Devendra Chauhan, Shivesh Sharma, Sheo Prasad, Nawal Kishore Dubey, Naleeni Ramawat (ed) Plant life under changing environment, 20th edn. Academic Press, Cambridge, Massachusetts. 513-541.

Gomez KA and Gomez AA (1984) Statistical procedures for agricultural research. Second Edition. IRRI. Los Banos, Laguna, Philippines.

Huang J, Hu T, Yasir M, Gao Y, Chen C, Zhu R, Wang X, Yuan $H$, Yang J (2018) Root growth dynamics and yield responses of rice (Oryza sativa L.) under drought-flood abrupt alternating conditions. EEB. 157: $11-25$.

IPCC. Summary for policymakers. In: Field C, et al, editors. Climate change 2014: Impacts, adaptation, and vulnerability. Part A: Global and sectoral aspects. Contribution of working group II to the fifth assessment report of the intergovernmental panel on climate change. Cambridge, United Kingdom and New York, NY, USA: Cambridge University Press. 32 p.

IRRI 2012 Methodologies for root drought studies in rice (Philipines: Int. Ric e Res. Inst.) pp 1-62.

Kamarudin ZS, Rafii MY, Mahmud TMM, Razi IM and Abdul RH (2018) Growth Performance and Antioxidant Enzyme Activities of Advanced Mutant Rice Genotypes under Drought Stress Condition. Agronomy. 8 (279).

Khalil A (2020) Rainfall trend analysis in the Mae Klong River Basin, Thailand. SJST. 42: 879-888.

Korres NE, Norsworthy JK, Burgos NR, Oosterhuis DM (2017) Temperature and drought impacts on rice production: An agronomic perspective regarding short- and long-term adaptation measures. Water resources and rural development. 9:12-27.

Korres NE, Norsworthy JK, Tehranchian P, Gitsopoulos TC, Loka DA, Oosterhuis DM, Moss S, Gealy D, Burgos 
NR, Miller R, Palhano M (2016) Cultivars to face climate change effects on crops and weeds: A review. Agron Sustain Dev. 36: (12).

Kumar R, Sarawgi AK, Ramos C, Amarante ST, Ismail AM, Wade WJ (2006) Partioning of dry matter during drought stress in rainfed lowland rice. Field Crop Res. 96: 455-465.

Kumar S, Dwivedi SK, Basu S, Kumar G, Mishra JS, Koley TK, Kumar A (2020) Anatomical, agromorphological and physiological changes in rice under cumulative and stage specific drought conditions prevailed in eastern region of India. Field Crop Res. 245: 107658.

Liu Y, Xu J, Ding Y, Wang Q, Li G, Wang S (2011) Auxin inhibits the outgrowth of tiller buds in rice (Oryza sativa L.) by down regulating OsIPT expression and cytokines biosynthesis in nodes. Aust J Crop Sci. 5: 169-174.

Lu H, Guo X, Wang Z, Zhen B, Liu C, Yang J (2017) Effects of alternative stress of drought and waterlogging on leaf character. J Irrig Drain E-ASCE. 1(47-51): 97-118.

Marcaida M, Tao L, Olivyn A, Gio KE, Marfel AF, Jianlong X, Yongming G, Zhikang L, Jauhar A (2014) Biomass accumulation and partitioning of newly developed Green Super Rice (GSR) cultivars under drought stress during the reproductive stage. Field Crop Res. (162): 30-38.

Mukamuhirwa A, Persson HH, Ortiz R, Nyamangyoku $O$, Prieto-Linde ML, Ekholm A, Johansson E (2019) Effect of intermittent drought on grain yield and quality of rice (Oryza sativa L.) grown in Rwanda. J Agron Crop Sci. 00: 1-11.

Nahar S, Vemireddy LR, Sahoo L, Tanti B (2018) Antioxidant protection mechanisms reveal significant response in drought-induced oxidative stress in some traditional rice of Assam. India Rice Sci. 25(4): 185-196.

Oh-e I, Saitoh K, Kuroda T (2007) Effects of high temperature on growth, yield and dry-matter production of rice grown in the paddy field. Plant Prod Sci. (10): 412-422.

Pandey V, Shukla A (2015) Acclimation and tolerance strategies of rice under drought stress. Rice Science. 22(4): 147-161.

Prathap V, Ali K, Singh A, Vishwakarma C, Krishnan V, Chinnusamy V, Tyagi A (2019) Starch accumulation in rice grains subjected to drought during grain filling stage. Int J Plant Physiol Biochem. (142): 440-451.

Shao G, Cui J, Yu SE, Lu B, Brian BJ, Ding J, She D (2015) Impacts of controlled irrigation and drainage on the yield and physiological attributes of rice. J Agricultural Water Management. (149): 156-165.

Skirycz A, Bodt SD, Obata T, Clercq ID, Claeys H, Rycke RD, Fernie AR (2010) Developmental stage specificity and the role of mitochondrial metabolism in the response of Arabidopsis leaves to prolonged mild osmotic stress. J Plant Physiol. (152): 226-244.

Sujinah \& Jamil A (2016) Mechanism response of rice under drought stress and tolerant varieties. Iptek Tanaman Pangan. 11: 1-8.
Suralta RR, Inukai Y, Yamauchi A (2010) Dry matter production in relation to root plastic development, oxygen transport, and water uptake of rice under transient soil moisture stresses. Plant Soil. 332: 87104.

Swapna S, Shylaraj KS (2017) Screening for osmotic stress responses in rice varieties under drought condition. Rice Science. 24: 253-263.

Upadhyaya H and Panda SK (2019) Drought stress responses and its management in rice. In: Mirza Hasanuzzaman Masayuki Fujita Kamrun Nahar Jiban Biswas (ed) Advances in Rice Research for Abiotic Stress Tolerance, 1st Edn. Amsterdam. Elsevier Inc. 177-200.

Wang H-Z, Zang L, MA J, LI X-Y, Zhang RP, Wang RQ (2010) Effect of water stress on reactive Oxygen species generation and protection system in rice during grain-filling stage. ASC. 9: 633-641.

Wang N, Huang M, Chen D, Xu S, Wei S, Jiang L (2013) Effects of water stress on root and yield of rice at different growth stages. Chin J Trop Crops. 9: 16501656.

Wassmann R, Jagadish S V K, Sumfleth $K$, Pathak $H$, Howell G, Ismail A, Serraj R, Redona E, Singh R K, Heuer S (2009) Regional vulnerability of climate change impacts on Asian rice production and scope for adaptation. Advances in Agronomy. 102: 91-133.

Xiong Q, Tang G, Zhong L, He H, Chen X (2018) Response to nitrogen deficiency and compensation on physiological characteristics, yield formation, and nitrogen utilization of rice. Front Plant Sci. (9): 1075.

Xiong $\mathrm{Q}$, Zhong L, Du J, Zhu C, Peng X, He X, Fu J, Ouyang L, Bian J, Hu L, Sun X, Xu J, Zhou D, Cai Y, Fu $H$, He $H$, Chen $X$ (2020) Ribosome profiling reveals the effects of nitrogen application translational regulation of yield recovery after abrupt droughtflood alternation in rice. Plant Physiol Bioch. (155): 42-58.

Yugi A (2011) Toleransi varietas padi gogo terhadap stres air berdasarkan kadar air tanah dan tingkat kelayuan. Agrin. 15(1): 1-7.

Zhang H, Xue Y, Wang Z, Yang J, Zhang J (2009) An alternate wetting and moderate soil drying regime improves root and shoot growth in rice. Crop Sci. (6): 2246.

Zhang Q, Gu X, Singh VP, Kong D, Chen X (2015) Spatiotemporal behavior of floods and droughts and their impacts on agriculture in China. Global Planet Change. 131: 63-72.

Zhu D, Wei H, Guo B, Dai Q, Wei C, Gao H, Hu Y, Cui P, Li M, Huo Z, Zhang $H$ (2017) The effects of chilling stress after anthesis on the physicochemical properties of rice (Oryza sativa L.) starch. Food Chem. (237): 936-941.

Zhu R, Wu F, Zhou S, Hu T, Huang J, Gao Y (2020) Cumulative effects of drought-flood abrupt alternation on the photosynthetic characteristics of rice. EEB. 169: 103901. 